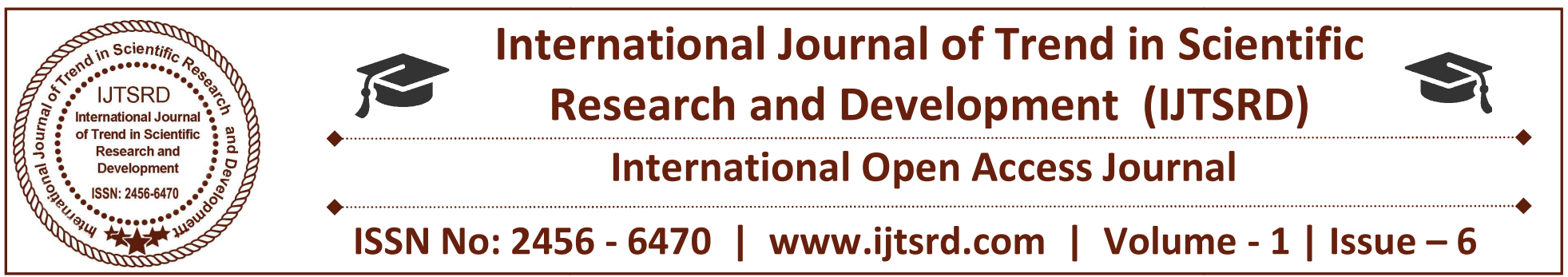

\title{
A Technological Survey on Privacy Preserving Data Publishing
}

\author{
Rajshree Srivastava \\ Department of Computer Science and Engineering \\ Jaypee Institute of Information Technology \\ Noida-128, (U.P.), India
}

\author{
Kritika Rani \\ Department of Computer Science and Engineering \\ Jaypee Institute of Information Technology \\ Noida-128, (U.P.), India
}

\begin{abstract}
There is an enormous collection of records of a particular individual in a system. These data needs to be highly secured. Due to easily availability of these records, the records or information is on high risk. These records are being used for the business purpose and as well as for the decision-making in the respective domain. However, any data that is in the raw form comes in the category of sensitive record as it contains the complete information of each particular individual. In the present scenario while publishing, the data mainly depend on the rules, policies and guidelines so that only the required information are published based on the agreements. Hence, privacy preserving and data publishing can be defined as tool and methods for publishing information while preserving privacy of the records. In this paper, there is a survey of various techniques and algorithm designed so far in order to preserve privacy of the data.
\end{abstract}

Keywords: k-nonymity, privacy preserving data publishing, l-diversity, slicing, anatomizations

\section{INTRODUCTION}

The original data of the individual is very sensitive so, there is risk of information breach. Original data of any particular individual can be his name, age, gender, employee code, company name, address, contact number, salary, etc. Therefore, the main challenge for the privacy of the data is to design methods and tools for publishing data in a risk-free environment.

In privacy preserving data publishing, there are two stages to successfully complete the process of publishing the record, these include data collection and data publisher. First task is to collect all data from the required domain of the owner and second task is to publish those collected data in the public with the security of the data such that the individual identity cannot be identified. Further, data publisher is the one who is having the original set of records, after collection of records the anonymiztion technique is applied in this phase only. After that is being, carry forward to the data recipient who publishes the data in the public. There are various anonymization techniques which are applied on the original table to make it more secure, these include generalization, suppression, etc.

Anonymization is defined as a process that removes or replaces the identity of the individual from any record. The original table or the original set of records must satisfy the any of the anonymization technique. In generalization the values or record are being generalized. For e.g. age 10-20 are being grouped into one, age 20-30 are being grouped into one and so on. While in the case of suppression, either the values or records are being deleted or it is being replaced with less distinct values in order to maintain uniformity. 


\section{RELATED WORK}

Privacy is considered one of the essential factors for publishing the data for preserving the data in the effective manner. In order to preserve the data there are various techniques which are being introduced in Privacy-preserving data publishing (ppdp). The first technique is k-anonymity, which states that if there is any given person specific detail it must produce a released data that guarantees that the individuals who are suspected for the data cannot be re-identified and

data remain useful [1]. Any published data is said to have adhering the property of k-anonymity if the information for each person contained in the released that cannot be identified from at least k-1 individuals

present [2]. This technique has some of the vulnerabilities due to which a new technique is being proposed known as 1-diversity. A q* block is said to 1 diverse if it contains at least 1 "well represented" values for the sensitive attributes(S)[5]. Any table is said to be 1-diverse if any only if every $\mathrm{q}^{*}$ block is diverse. It is easy to achieve but practical it is very difficult to achieve. The key idea is to limit the disclosure risk, for this to achieve there is requirement to measure the disclosure risk of the anonymized table. The limitation of 1-diversity is that it is limited upto some extent on its assumption of the adversial knowledge. T-closenesss proposed a novel notation that formalizes the idea of background knowledge [7].

In order to calculate the distance between the values of the sensitive attributes Earth movers distance is considered best. Any equivalence class is said to have $\mathrm{t}$-closeness if the distance between the distribution of a sensitive attribute in the present class and the distribution of the attribute present is the complete table is not more than the threshold value. Slicing is one of the new techniques which is introduced that partitions data both horizontally and vertically [11].
In slicing, there is random grouping of data due to which we does not have a clear scenario. There is information loss further in this case. An easy way to comply with the conference paper formatting requirements is to use this document as a template and simply type your text into it. [13]To address the limitation of slicing, overlapping slicing is being introduced that handless the data attributes on the concept of fuzzy clustering. It ensures the utility of the published data by adding attribute in the column so that attributes, which are duplicate, are combined to get better correlation value. It fails to support high dimensional data $\log$ with the multiple sensitive data. [16]In order of overcome the drawback of overlapping slicing Anatomization technique is being introduced. In this technique, the limitation of the overlapping slicing is being solved and further the loss of information is low. It strictly follows the property of k-anonymity as well as 1-diversity. The approach of anatomy states that if there are two tables with join attributes and it goes for publishing, then it will correspond to those two tables that come in the category of lossy. Different types of techniques, are being discussed and compared in the table. 


\section{TABLE I}

\section{COMPARATIVE PAPER STUDIED [2002- 2016]}

\begin{tabular}{|c|c|c|c|c|c|c|}
\hline YEAR & $\begin{array}{l}\text { NAME } \\
\text { THE PAPER }\end{array}$ & $\begin{array}{l}\text { AUTHOR } \\
\text { AUTO }\end{array}$ & $\begin{array}{l}\text { TECHNIQU } \\
\text { E USED }\end{array}$ & $\begin{array}{l}\text { ALGORIT } \\
\text { HM } \\
\text { APPLIED }\end{array}$ & $\begin{array}{l}\text { DISADVANTA } \\
\text { GES }\end{array}$ & ADVANTAGES \\
\hline 2002 & $\begin{array}{l}\text { Achieving k- } \\
\text { Anonymity } \\
\text { Privacy } \\
\text { Protection } \\
\text { Using } \\
\text { Generalization } \\
\text { and } \\
\text { Suppression }\end{array}$ & L.Sweeney & MinGen & $\begin{array}{l}\text { Global, } \\
\text { bottom-up, } \\
\text { complete, } \\
\text { impractical }\end{array}$ & $\begin{array}{l}\text { The two types of } \\
\text { attack: } \\
\text { background } \\
\text { knowledge and } \\
\text { homogeneity is } \\
\text { possible. } \\
\text { *the problem is } \\
\text { NP-hard } \\
\text { *the search space } \\
\text { is exponential in } \\
\text { this case. }\end{array}$ & $\begin{array}{l}\text { It supports identity } \\
\text { disclosure. }\end{array}$ \\
\hline 2004 & $\begin{array}{l}\text { Bottom-Up } \\
\text { Generalization: } \\
\text { A Data Mining } \\
\text { Solution to } \\
\text { Privacy } \\
\text { Protection }\end{array}$ & Wang & $\begin{array}{l}\text { Bottom-up- } \\
\text { generalization }\end{array}$ & $\begin{array}{l}\text { Global, } \\
\text { bottom-up, } \\
\text { greedy }\end{array}$ & $\begin{array}{l}\text { *in this user may } \\
\text { not any point or } \\
\text { time can stop } \\
\text { and can obtain a } \\
\text { generalized table } \\
\text { which is fully } \\
\text { satisfying the } \\
\text { property of } \\
\text { anonymity. }\end{array}$ & $\begin{array}{lrr}\begin{array}{l}\text { *shows } \\
\text { transformation }\end{array} & \text { the } \\
\text { specific data } & \text { of less } \\
\text { specific data. } & \\
\text { *it shows } & \text { better } \\
\text { scalability } & \end{array}$ \\
\hline 2005 & $\begin{array}{l}\text { Top-Down } \\
\text { Specialization } \\
\text { for information } \\
\text { and privacy } \\
\text { preservation. }\end{array}$ & Fung & $\begin{array}{l}\text { Top-Down } \\
\text { Specialization }\end{array}$ & $\begin{array}{l}\text { Global, } \\
\text { top-down, } \\
\text { greedy }\end{array}$ & $\begin{array}{l}\text { It does not } \\
\text { handle numerical } \\
\text { attributes. }\end{array}$ & $\begin{array}{l}\text { *preserves } \\
\text { information utility and } \\
\text { also privacy of the } \\
\text { individual. } \\
\text { * in this user can stop at } \\
\text { any point or time and } \\
\text { can obtain a generalized } \\
\text { table which is fully } \\
\text { satisfying the property of } \\
\text { anonymity. }\end{array}$ \\
\hline 2005 & $\begin{array}{lr}\text { Incognito: } & \\
\text { Efficient } & \text { full- } \\
\text { domain } & \mathrm{k}- \\
\text { anonymity } & \end{array}$ & LeFevre & Incognito & $\begin{array}{l}\text { Global, } \\
\text { bottom-up, } \\
\text { hierarchy- } \\
\text { based, } \\
\text { complete }\end{array}$ & $\begin{array}{l}\text { In this the surely } \\
\text { of minimality is } \\
\text { not present. In } \\
\text { this guarantee of } \\
\text { minimal data is } \\
\text { not possible. }\end{array}$ & $\begin{array}{l}\text { *It is feasible for large } \\
\text { databases } \\
\text { *in this the problem of } \\
\text { Min. Gen. Algorithm is } \\
\text { been solved. }\end{array}$ \\
\hline 2006 & $\begin{array}{l}\text { Mondrian } \\
\text { Multidimension } \\
\text { ak-anonymity }\end{array}$ & LeFevre & Mondrian & $\begin{array}{l}\text { Local, top- } \\
\text { down, } \\
\text { partition- } \\
\text { based, } \\
\text { greedy }\end{array}$ & $\begin{array}{l}\text { *in this } \\
\text { anonymization is } \\
\text { quite sensitive if } \\
\text { there will be any } \\
\text { small change in } \\
\text { the synthetic data } \\
\text { there will be } \\
\text { variation in the } \\
\text { result. }\end{array}$ & $\begin{array}{l}* \text { in this also the problem } \\
\text { of Min. Gen Algorithm } \\
\text { is solved. }\end{array}$ \\
\hline 2006 & 1-diversity & A.Machanavajjhala & $\begin{array}{l}\text { Bayes } \\
\text { Optimal } \\
\text { Privacy }\end{array}$ & & $\begin{array}{l}\text { *attribute and } \\
\text { record linkage is } \\
\text { possible. } \\
\text { *limitation is in } \\
\text { the practice as } \\
\text { multiple } \\
\text { adversaries have } \\
\text { different levels } \\
\text { of knowledge. } \\
\text { *extension of } \\
\text { handling } \\
\text { multiple } \\
\text { sensitive }\end{array}$ & $\begin{array}{l}\text { *It protects from the } \\
\text { background knowledge } \\
\text { attack. } \\
\text { *it supports identity } \\
\text { disclosure. }\end{array}$ \\
\hline
\end{tabular}


International Journal of Trend in Scientific Research and Development (IJTSRD) ISSN: 2456-6470

\begin{tabular}{|c|c|c|c|c|c|c|}
\hline & & & & & $\begin{array}{l}\text { attributes, and to } \\
\text { develop methods } \\
\text { for continuous } \\
\text { sensitive } \\
\text { attributes }\end{array}$ & \\
\hline 2006 & $\begin{array}{l}\text { Anatomy: a } \\
\text { simple } \\
\text { approach for } \\
\text { preserving data }\end{array}$ & X.Xiao,Y.Tao & $\begin{array}{l}\text { Anatomy } \\
\text { technique }\end{array}$ & $\begin{array}{l}\text { Linear } \\
\text { algorithm }\end{array}$ & & $\begin{array}{l}\text { *obeys 1-diversity } \\
\text { *overcome the problem } \\
\text { of generalization. }\end{array}$ \\
\hline 2007 & $\begin{array}{l}\text { T Closeness: } \\
\text { Privacy Beyond } \\
\text { k-anonymity } \\
\text { and l-diversity }\end{array}$ & $\begin{array}{l}\text { N.Li,T.Li and } \\
\text { S.Venkatasubra- } \\
\text { manian, }\end{array}$ & $\begin{array}{l}\text { For the } \\
\text { calculation } \\
\text { the distance } \\
\text { EMD is been } \\
\text { used. }\end{array}$ & & $\begin{array}{l}\text { *vulnerable to } \\
\text { probabilistic } \\
\text { attack } \\
*_{\text {vulnerable to }} \\
\text { similarity and } \\
\text { skewness attack. }\end{array}$ & $\begin{array}{l}\text { *protects against identity } \\
\text { disclosure. }\end{array}$ \\
\hline 2010 & $\begin{array}{l}\text { A survey : } \\
\text { Recent } \\
\text { Development } \\
\text { on Privacy- } \\
\text { preserving and } \\
\text { Data publishing }\end{array}$ & $\begin{array}{l}\text { B.C.M.Fung, } \\
\text { R.Chen, P.S.Yu }\end{array}$ & & & & $\begin{array}{l}\text { *outline the publishing } \\
\text { technologies and the } \\
\text { model. } \\
\text { *it ehncances the } \\
\text { knowledge about } \\
\text { advantages and } \\
\text { limitation of all privacy } \\
\text { preserving data } \\
\text { publishing techniques } \\
\text { defined so far. }\end{array}$ \\
\hline 2012 & $\begin{array}{l}\text { Slicing: A new } \\
\text { Approach to } \\
\text { privacy } \\
\text { Preserving } \\
\text { Publishing }\end{array}$ & $\begin{array}{l}\text { Tiancheng Li, } \\
\text { Ninghui Li, Jian } \\
\text { Zhang, Ian Molloy }\end{array}$ & $\begin{array}{l}\text { New } \\
\text { anonymizat- } \\
\text { ion technique } \\
\text { known as } \\
\text { slicing } \\
\text { technique. }\end{array}$ & $\begin{array}{l}\text { Slicing } \\
\text { algorithm }\end{array}$ & $\begin{array}{l}\text { *they have } \\
\text { considered } \\
\text { slicing where } \\
\text { only one } \\
\text { attribute is in one } \\
\text { particular } \\
\text { column only. } \\
\text { *random } \\
\text { grouping is not } \\
\text { best way of } \\
\text { completing the } \\
\text { task. values of } \\
\text { *the in the } \\
\text { data in the } \\
\text { column of } \\
\text { bucket are } \\
\text { arranged } \\
\text { randomly. }\end{array}$ & $\begin{array}{lr}* \text { it overcomes } & \text { the } \\
\text { limitation } & \text { of } \\
\text { generalization } & \text { and } \\
\text { bucketization. } & \\
\text { *it protects against } \\
\text { privacy threats. }\end{array}$ \\
\hline 2013 & $\begin{array}{l}\text { Data Slicing } \\
\text { Technique to } \\
\text { Privacy } \\
\text { Preserving And } \\
\text { Data Publishing }\end{array}$ & $\begin{array}{l}\text { Alphonsa Vedangi, } \\
\text { V.Anandam }\end{array}$ & $\begin{array}{l}\text { Slicing } \\
\text { technique }\end{array}$ & $\begin{array}{l}\text { Slicing } \\
\text { algorithm }\end{array}$ & $\begin{array}{l}\text { *they have } \\
\text { considered } \\
\text { slicing where } \\
\text { only one } \\
\text { attribute is in one } \\
\text { particular } \\
\text { column only. } \\
\text { *random } \\
\text { grouping is not } \\
\text { best way of } \\
\text { completing the } \\
\text { task. values of } \\
\text { *the in the } \\
\text { data of the } \\
\text { column are } \\
\text { bucket } \\
\text { arranged } \\
\text { randomly. }\end{array}$ & $\begin{array}{lr}* \text { it overcomes } & \text { the } \\
\text { limitation } & \text { of } \\
\text { generalization } & \text { and } \\
\text { bucketization. } & \\
* \text { it protects against } \\
\text { privacy threats. }\end{array}$ \\
\hline 2014 & Data & J.Yang, & Decompositi- & Overlap & *it cannot handle & *Data \\
\hline
\end{tabular}


International Journal of Trend in Scientific Research and Development (IJTSRD) ISSN: 2456-6470

\begin{tabular}{|c|c|c|c|c|c|c|}
\hline & $\begin{array}{l}\text { Anonymous } \\
\text { Method based } \\
\text { on Overlapping } \\
\text { Slicing }\end{array}$ & J.Zhang & on technique & g algorithm & $\begin{array}{l}\text { multiple } \\
\text { sensitive } \\
\text { attribute data. }\end{array}$ & $\begin{array}{l}\text { preserved in a better } \\
\text { way. } \\
\text { *attribute duplication is } \\
\text { more in one column. } \\
\text { * the problem of the } \\
\text { slicing is solved in this } \\
\text { case. }\end{array}$ \\
\hline 2016 & $\begin{array}{l}\text { Anatomization } \\
\text { with slicing: a } \\
\text { new privacy } \\
\text { preservation } \\
\text { approach for } \\
\text { multiple } \\
\text { sensitive } \\
\text { attributes }\end{array}$ & $\begin{array}{l}\text { V.Shyamala Susan } \\
\text {,T.Christopher }\end{array}$ & $\begin{array}{l}\text { Anonymizati } \\
\text { on Technique }\end{array}$ & $\begin{array}{l}\text { Advanced } \\
\text { new } \\
\text { clustering } \\
\text { algorithim } \\
\text { and } \\
\text { Minkowsi } \\
\text { distance } \\
\text { measure } \\
\text { algorithm }\end{array}$ & $\begin{array}{l}* \text { it is not } \\
\text { applicable on } \\
\text { quasi-identifier } \\
\text { table(QIT)and } \\
\text { sensitive } \\
\text { table(SA) }\end{array}$ & $\begin{array}{l}\text { *It can handle multiple } \\
\text { sensitive attribute data. }\end{array}$ \\
\hline
\end{tabular}


TABLE II

COMPARITIVE STUDY OF PRIVACY MODELS AND THE TECHNIQUES

\begin{tabular}{|c|c|c|c|c|}
\hline $\begin{array}{l}\text { MODELS OF } \\
\text { PRIVACY }\end{array}$ & K-ANONYMITY & L-DIVERSITY & T-CLOSENESS & SLICING \\
\hline Initiation & [2002] & [2006] & [2007] & [2012] \\
\hline Attacks & $\begin{array}{l}\text { Background attack } \\
\text { and as well as } \\
\text { homogeneity } \\
\text { attack }\end{array}$ & $\begin{array}{l}\text { Skewness attack and } \\
\text { attack of similarity. }\end{array}$ & $\begin{array}{l}\text { Skewness attack and as } \\
\text { well as attack of } \\
\text { similarity. }\end{array}$ & $\begin{array}{l}\text { It is not vulnerable to } \\
\text { this type of attack. }\end{array}$ \\
\hline Disclosure & $\begin{array}{l}\text { Fails to support } \\
\text { attribute disclosure } \\
\text { but supports } \\
\text { identity disclosure. }\end{array}$ & $\begin{array}{l}\text { does not support } \\
\text { attribute disclosure. }\end{array}$ & It does not prevent. & $\begin{array}{l}\text { It prevents attribute } \\
\text { disclosure risk. }\end{array}$ \\
\hline Ease & $\begin{array}{l}\text { It is simple and } \\
\text { easy to understand } \\
\text { and can be } \\
\text { achieved. }\end{array}$ & $\begin{array}{l}\text { It may be difficult to } \\
\text { achieve. }\end{array}$ & $\begin{array}{l}\text { It is somewhat easy to } \\
\text { achieve in comparison to } \\
\text { l-diversity. }\end{array}$ & It is easy to achieve. \\
\hline Categorization & $\begin{array}{l}\text { It is a privacy } \\
\text { model. }\end{array}$ & $\begin{array}{l}\text { It comes under privacy- } \\
\text { preserving and data- } \\
\text { publishing } \\
\text { categorization. }\end{array}$ & $\begin{array}{l}\text { It comes under privacy- } \\
\text { preserving and data } \\
\text { publishing } \\
\text { categorization. }\end{array}$ & $\begin{array}{l}\text { It comes under the } \\
\text { category of privacy- } \\
\text { preserving and data } \\
\text { publishing(ppdp) } \\
\text { categorization. }\end{array}$ \\
\hline $\begin{array}{c}\text { Privacy against } \\
\text { attacker }\end{array}$ & $\begin{array}{lr}\text { There is } & \text { no } \\
\text { guarantee } & \text { of } \\
\text { privacy against } \\
\text { attacker } & \text { using } \\
\text { background } & \\
\text { knowledge. } & \end{array}$ & 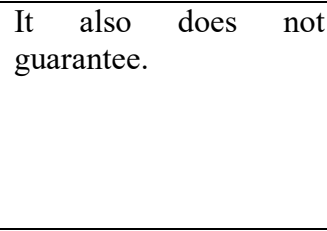 & 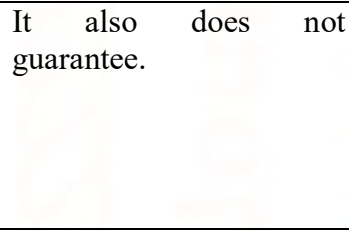 & $\begin{array}{l}\text { It may and mot } \\
\text { guarantee against the } \\
\text { privacy against attacker. }\end{array}$ \\
\hline Probabilistic Attack & $\begin{array}{l}\text { In this } \\
\text { probabilistic attack } \\
\text { is not possible. }\end{array}$ & $\begin{array}{l}\text { In this probabilistic } \\
\text { attack is not possible. }\end{array}$ & $\begin{array}{l}\text { Probabilistic attack is } \\
\text { possible. }\end{array}$ & $\begin{array}{l}\text { Probabilistic attack is not } \\
\text { possible. }\end{array}$ \\
\hline Record Linkage & $\begin{array}{l}\text { In this record } \\
\text { linkage is possible. }\end{array}$ & $\begin{array}{l}\text { Record linkage is } \\
\text { possible. }\end{array}$ & $\begin{array}{l}\text { In this record linkage is } \\
\text { possible }\end{array}$ & $\begin{array}{l}\text { In this record linkage is } \\
\text { not possible. }\end{array}$ \\
\hline Attribute Linkage & $\begin{array}{l}\text { In this attribute } \\
\text { linkage is possible. }\end{array}$ & $\begin{array}{l}\text { In this attribute linkage } \\
\text { is possible. }\end{array}$ & In this attribute linkage & $\begin{array}{l}\text { In this attribute linkage } \\
\text { is also not possible. }\end{array}$ \\
\hline $\begin{array}{l}\text { Monotonocity } \\
\text { Property }\end{array}$ & $\begin{array}{l}\text { It satisfies the } \\
\text { property } \\
\text { of } \\
\text { monotonicity } \\
\text { property. }\end{array}$ & $\begin{array}{l}\text { It also satisfies the } \\
\text { property of } \\
\text { monotonicity } \\
\text { property. }\end{array}$ & $\begin{array}{c}\text { It may or may not satisfy } \\
\text { the monotonicity } \\
\text { property. }\end{array}$ & $\begin{array}{l}\text { It satisfies the property } \\
\text { of monotonicity. }\end{array}$ \\
\hline Categorization & $\begin{array}{l}\text { It does not have } \\
\text { any categorization. }\end{array}$ & $\begin{array}{l}\text { It has been categorized } \\
\text { into } 3 \text { types. }\end{array}$ & $\begin{array}{l}\text { It does not have any } \\
\text { category-zation. }\end{array}$ & $\begin{array}{l}\text { It has been categorized } \\
\text { into two categories: } \\
\text { slicing and overlapped } \\
\text { slicing. }\end{array}$ \\
\hline Record Linkage & $\begin{array}{l}\text { In this record } \\
\text { linkage is possible. }\end{array}$ & $\begin{array}{l}\text { Record linkage is } \\
\text { possible. }\end{array}$ & $\begin{array}{l}\text { In this record linkage is } \\
\text { possible. }\end{array}$ & $\begin{array}{l}\text { In this record linkage is } \\
\text { not possible. }\end{array}$ \\
\hline Data Utility loss & Is medium & Is medium & $\begin{array}{l}\text { In this data utility loss is } \\
\text { high. }\end{array}$ & $\begin{array}{l}\text { Is very low in the case of } \\
\text { high dimensionality. }\end{array}$ \\
\hline $\begin{array}{l}\text { Membership } \\
\text { Disclosure }\end{array}$ & Yes it is possible & Yes it is possible & No it is not possible & No it is not possible. \\
\hline High dimensionality & $\begin{array}{l}\text { It cannot be } \\
\text { applied on high } \\
\text { dimensionality. }\end{array}$ & $\begin{array}{l}\text { It does not support high } \\
\text { dimensionality. }\end{array}$ & $\begin{array}{l}\text { it also does not support } \\
\text { high dimensionality. }\end{array}$ & $\begin{array}{l}\text { It supports } \\
\text { dimensionality. }\end{array}$ \\
\hline
\end{tabular}




\section{CONCLUSION}

In this paper, there is survey of the different techniques which are being introduced till now in order to preserve privacy of the record. The last technique i.e. Anatomization is considered one of the best technique so far among all the techniques. Future work can be introduction to new technique where loss of information is less and is more highly secured. A new technique should strongly follow the property of k-anonymity , 1-diversity and as well as t-closeness , so that the co-relation among the attributes which are less can be grouped together and then anonymization technique can be applied.

\section{REFERENCES}

[1] L.Sweeney, "K-anonymity: a model for protecting privacy", International Journal Uncertain Fuzz, 10(5):577-570, 2002(a)

[2] L.Sweeney, "Achieving k-anonymity privacy protection using generalization and suppression", International Journal Uncertain Fuzz, 10(6): 571-588, 2002(b)

[3] K.LeFevre, D.J.DeWitt and R.Ramakrishnan, "Incognito: Efficient full domain k-anonymity", In SIGMOD, pages 49-60, 2005

[4] A.Machanavajjhala, J.Gehrke, D.Kifer and M.Venkitasubramaniam, "1-diversity: Privacy beyond k-anonymity. In Proc. 22nd International Conference Data Engg(ICDE), page 24, 2006

[5] A.Machanavajjhala, Kifer,D.,Gehrke, J., and Venkitasubramaniam.M, "L-diversity: privacy beyond k-anonymity", ACM Trans Knowledge Discover Data 1(1):1-52, 2007

[6] X.Xiao and Y.Tao, "Anatomy: simple and effective privacy preservation", In VLDB '06: Proceedings of the 32nd International conference on Very large data bases, pages 139-150, VLDB Endowment, 2006

[7] N.Li, T.Li, and S.Venkatasubramanian, "tcloseness: privacy beyond k-anonymity and 1- diversity", Proc. IEEE International Conferenece data Eng.(ICDE), pp. 106-115, 2007

[8] D.J.Martin, D.Kifer, A.Machanavajjhala, J.Gehrke and J.Y.Halpern, "Worst-case background knowledge for privacy-preserving data publishing", In ICDE, pages 126-135, 2007

[9] H.Tian, et al. W.Zhang, "Extending 1-diversity for better Data Anonymization.", Sixth International Conference on Information Technology: New Generations, 2009

[10] B.C.M.Fung, K.Wang, R.Chen and P.S.Yu, "Privacy-preserving data publishing: A survey on recent developments", ACM Computing Surveys, 2010

[11] T.Li,N.li, J.Zhang and L.Molloy, "Slicing: a new approach for privacy preserving data publishing", In IEEE Transactions on knowledge and Data Engineering, volume 24, page 561-574, 2012

[12] A.Vedangi, V.Anandam, "Data slicing technique to privacy preserving and data publishing", International Journal of Research in Engineering and Technology, 2(10):120-6, 2013

[13] J.Yang, Z.Li,J.Zhang, "A data anonymous method based on overlapping slicing", Proceedings of the IEEE 18th International Conference o Computer Supported Cooperative Work in Design, 2014

[14] A.A.Dhaigude, P.Kumar, "Improved Slicing Algorithm for greater utility in privacy preserving data publishing", International Journal of Data Engineering (IJDE), Volume (5): Issue (2); 2014

[15] M.D.Kamalesh, B.Bharathi, "Slicing an efficient Transaction Data Publication and For Data Publishing", International Journal of Science and Technology, Volume 8(S8), 306-309, 2015

[16] V.Shyamala Susan and T.Christopher, "Anatomisation with slicing: a new privacy preservation approach for multiple sensitive attributes", Springer Plus (2016)5:964 